\title{
PENGARUH HARAPAN LAMA SEKOLAH, RATA - RATA LAMA SEKOLAH TERHADAP TINGKAT PENGANGGURAN TERBUKA DI KABUPATEN / KOTA PROVINSI RIAU
}

\author{
Nelva Siskawati ${ }^{1}$, Roberta Zulfhi Surya ${ }^{2}$, Endy Sudeska ${ }^{3}$ \\ ${ }^{1}$ Prodi Manajemen Fakultas Ekonomi Dan Bisnis, Universitas Islam Indragiri \\ ${ }^{2}$ Prodi Teknik Industri Fakultas Teknik dan Ilmu Komputer, Universitas Islam Indragiri \\ 3Prodi Teknik Sipil Fakultas Teknik dan Ilmu Komputer, Universitas Islam Indragiri \\ Email: nelvasiskawatimgt@gmail.com (korespondensi)
}

\begin{abstract}
This study aims to determine how many the effect of Expected Years of Schooling and Average Length of Schooling on Open Unemployment Rates in the District/City of Riau Province, from 2017 to 2020 with a total of 44 samples. The data taken is sourced from secondary data, namely from the Central Statistics Agency of Indragiri Hilir Regency. The data analysis technique used is Multiple Linear Regression Analysis. The final result can be concluded that the variables of Average Length of School and Expected Length simultaneously or together have an influence on the open unemployment rate even though in a small percentage.
\end{abstract}

Keywords: Expected Length of Schooling, Average Length of Schooling, Open Unemployment Rate.

\section{Abstrak}

Penelitian ini bertujuan mengetahui seberapa besar pengaruh dari Harapan Lama Sekolah dan Rata - Rata Lama Sekolah terhadap Tingkat Pengangguran Terbuka di Kabupaten/Kota Provisinsi Riau, mulai tahun 2017 sampai tahun 2020 dengan jumlah 44 sampel. Data yang diambil bersumber dari data sekunder yaitu dari Badan Pusat Statistik Kabupaten Indragiri Hilir. Teknik Analisis Data yang digunakan adalah Analisis Regresi Linear Berganda. Hasil akhir dapat di simpulkan bahwa variabel Rata- Rata Lama sekolah dan harapan Lama secara simultan atau secara bersama-sama memiliki pengaruh terhadap tingkat pengangguran terbuka walaupun dalam persentase yang sedikit.

Kata kunci: Harapan Lama Sekolah, Rata-rata Lama Sekolah, Tingkat Pengangguran Terbuka.

\section{PENDAhUlUAN}

Provinsi Riau yang memiliki 12 Kabupaten/kota disebut sebagai daerah yang terluas di Sumatera. Berdasarkan hasil penghitungan Badan Pusat Statistik ( BPS ) bahwa Penduduk yang terbanyak berada di Kota Pekanbaru, sekitar $16,40 \%$ dari seluruh penduduk di Riau. Sedangkan jumlah penduduk yang paling sedikit berada di daerah Kepulauan Meranti, yaitu sekitar $2,67 \%$ dari pendududuk yang berada di Provinsi Riau itu sendiri.

Berdasarkan Data dari Badan Pusat Statistik ( BPS ) Provinsi Riau, diketahui bahwa tahun 2020 capaian pembangunan manusia yang diukur dari Indeks Pembangunan Manusia ( IPM ) Riau berstatus tinggi dengan rata - rata pertumbuhan 0,52 \%. Dan dimana penduduk usia kerja yang termasuk dalam kelompok pengangguran atau yang sering disebut dengan Tingkat Pengangguran Terbuka untuk Provinsi Riau di tinjau dari kondisi Februari 2021 mengalami penurunan. Faktor yang sangat berpengaruh pada pasar tenaga kerja adalah dari pendidikan masyarakat. Dengan adanya Program wajib Belajar 9 tahun membawa perkembangan positif dalam meningkatkan pembangunan sumber daya manusia. Hal ini juga dapat dilihat dari pertumbuhan Harapan Lama Sekolah ( HLS ) dari tahun 2017 - 2020 dengan rata - rata tumbuh berkisar 0,71 \%. Dan Pertumbuhan Rata - Rata Lama Sekolah ( RLS ) terus tumbuh dalam kisaran 0,64\%. 
Berdasarkan data - data tersebut yang menunjukkan adanya data penurunan tingkat pengangguran terbuka serta adanya kemajuan - kemajuan dalam pertumbuhan Harapan Lama Sekolah ( HLS ) dan Rata Rata lama sekolah ( RLS ) di Provinsi Riau, di mana tujuan yang paling utama dalam pembangunan ekonomi yaitu dengan meningkatkan taraf hidup yang dapat dilakukan dengan cara menekan angka pengangguran dan meningkatkan kesempatan kerja. Sehingga dapat diasumsikan bahwa ada pengaruh Harapan Lama Sekolah ( HLS ) dan Rata - Rata Lama Sekolah ( RLS ) terhadap Tingkat Pengangguran Terbuka.

Menurut Todaro (2006) dalam jurnalnya Deasy Dwi Ramiayu mengatakan bahwa Semakin lama masyarakat menempuh dan lulus tamatan pendidikan formal, maka semakin tinggi pula kemampuan dan kesempatan masyarakat tersebut untuk bekerja, sehingga dapat menurunkan tingkat pengangguran terbuka.

Namun berbeda dengan hasil penelitian dari Imarotus Suaidah dan Hendry Cahyono yang dituangkan dalam jurnal penelitiannya mengatakan bahwa Variabel tingkat pendidikan memiliki pengaruh positif yang signifikan terhadap tingkat pengangguran. Dengan kata lain dapat diartikan bahwa semakin tinggi tingkat pendidikan akan semakin tinggi tingkat pengangguran. Adanya Peningkatan dalam pendidikan dapat di lihat dengan meningkatnya jumlah Iulusan SMA/Aliyah sehingga akan meningkatkan kemampuan tenaga kerja yang selanjutnya akan menambah daya saing tenaga kerja tersebut yang berdampak kepada peningkatan pengangguran.

Dapat dilihat dari gambar 1 bahwa dari 12 Kabupaten/Kota Provinsi Riau, sama sama memiliki angka perkembangan yang berfluktuatif untuk Harapan Lama Sekolah dan Rata - rata lama sekolah, dimana perkembangan angka Harapan Lama sekolah jauh lebih tinggi dibanding dengan rata rata lama sekolah. Pada grafik di atas juga dapat kita lihat bahwa perkembangan angka tingkat pengangguran terbuka berada di bawah garis harapan lama sekolah dan rata -rata lama sekolah.

Berdasarkan data yang penulis dapat pada latar belakang diatas, maka penulis ingin mengetahui seberapa besar pengaruh Harapan Lama Sekolah (HLS) dan Rata rata lama sekolah (RLS) terhadap Tingkat Pengangguran Terbuka?

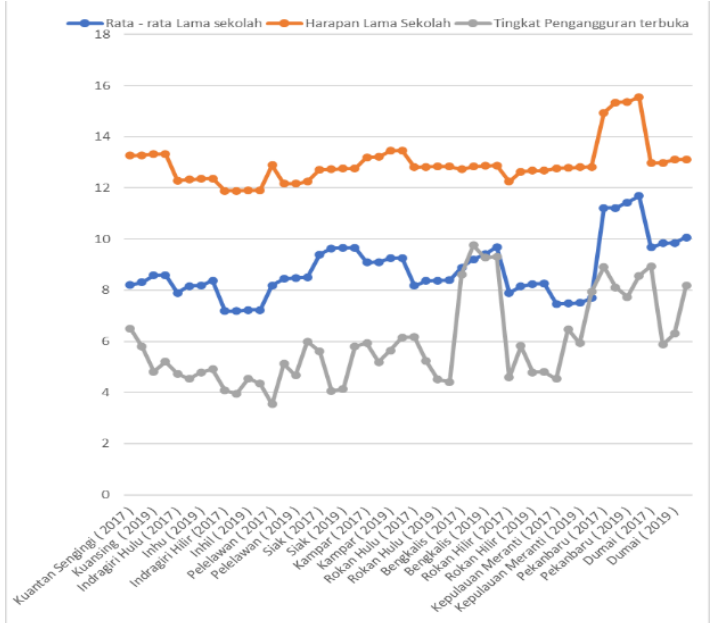

Gambar 1. Angka Harapan Lama sekolah (Sumber: BPS. INHIL data olahan )

\section{TINJAUAN PUSTAKA}

\subsection{Pengangguran}

Badan Pusat Statistik ( BPS ) mendefenisikan Pengangguran Terbuka (open unemployment) adalah seluruh angkatan kerja yang mencari pekerjaan, baik yang mencari pekerjaan pertama kali maupun yang pernah bekerja sebelumnya.

Dalam bukunya Sukirno (2004: 328) menjelaskan bahwa ada dua cara untuk menggolongkan jenis - jenis pengangguran yaitu berdasarkan sumber atau penyebab yang mewujudkan pengangguran dan ciri pengangguran tersebut. Berdasarkan penyebabnya, pengangguran dibagi atas :

a. Pengangguran Normal atau Friksional adalah jenis pengangguran yang disebabkan penganggur ingin mencari pekerjaan yang lebih baik.

b. Pengangguran Siklikal adalah jenis pengangguran yang disebabkan merosotnya kegiatan ekonomi atau karena terlampau kecilnya permintaan agregat di dalam perekonomian dibanding penawaran agregatnya.

c. Penganguran Struktural adalah jenis pengangguran yang disebabkan adanya perubahan struktur kegiatan ekonomi.

d. Pengangguran Teknologi adalah pengangguran yang disebabkan adanya penggantian SDM dengan teknologi/mesin dalam proses produksi.

Berdasarkan cirinya Pengangguran terbagi atas:

a. Pengangguran terbuka dimana pengangguran ini tercipta sebagai akibat pertambahan lowongan pekerjaan yang lebih rendah dari pertambahan tenaga kerja.

b. Pengangguran tersembunyi adalah pengangguran ini tercipta sebagai akibat jumlah pekerja dalam suatu kegiatan 
ekonomi lebih banyak dari yang sebenarnya yang diperlukan.

c. Pengangguran bermusim adalah pengangguran yang tercipta akibat musim yang ada, biasanya pengangguran ini terdapat di sektor pertanian dan perikanan

d. Setengah menganggur adalah pengangguran yang tercipta akibat tenaga kerja bekerja tidak sepenuh dan jam kerja mereka adalah jauh lebih rendah dari yang normal.

\subsection{Harapan Lama Sekolah (HLS)}

Harapan lama sekolah adalah perhitungan lamanya jumlah waktu sekolah (dalam tahun) yang akan dirasakan oleh anak pada umur tertentu dimasa mendatang. Harapan lama sekolah dihitung untuk penduduk berusia 7 tahun keatas. Indikator harapan lama sekolah digunakan untuk mengetahui kondisi pembangunan sistem pendidikan diberbagai jenjang yang ditunjukan dalam lamanya pendidikan (dalam tahun) yang diharapkan dapat ditempuh oleh setiap anak sampai usia 12 tahun keatas.

Badan Pusat Statistik (2020) Angka Harapan Lama Sekolah merupakan metode pengembangan dari metode lama yaitu RataRata Lama Sekolah dan Angka Buta Huruf, dimana Harapan Lama Sekolah (HLS) di gunakan dan dikaji utuh sebagai salah satu indikator dari IPM mulai tahun 2010.

\subsection{Rata - Rata Lama Sekolah}

Badan Pusat Statistik (2020) Rata - rata Lamanya Sekolah (RLS) merupakan rata rata lamanya (tahun) pendidikan formal yang ditempuh oleh penduduk usia 25 tahun keatas.

Sirilius Seran (2015) dalam jurnal penelitiannya mengatakan bahwa orang yang memperoleh pendidikan (formal) hingga tamat perguruan tinggi memiliki kemampuan intelek yang relatif lebih tinggi dari orang yang hanya tamat sekolah menengah. Oleh karena itu Variasi Fleksibelitas dalam hal penentuan pilihan jenis dan atau lapangan pekerjaan untuk mereka yang berkualitas tinggi karena berpendidikan tinggi lebih terbuka. Mereka ini relatif lebih rewel/selektif memilih pekerjaan. Besaran/tingkat upah, dan kenyamanan lingkungan tempat kerja, dapat menjadi faktor pemicu akan hal ini. Bahkan beberapa diantaranya akan lebih memilih untuk menganggur (sementara) dari pada bekerja.

\section{METODOLOGI PENELITIAN}

Penelitian ini termasuk jenis penelitian kuantitatif dengan menggunakan sumber data sekunder yang diperoleh dari Data Publikasi Badan Pusat Statitik Indragiri Hilir.

Populasi yang digunakan dalam penelitian ini adalah seluruh data time series (data deretan waktu) Rata -rata Lama Sekolah, Harapan Lama Sekolah Dan tingkat Pengangguran Terbuka dari 12 Kabupaten/ Kota Di Provinsi Riau selama periode 20172020.

Sampel yang digunakan dalam penelitian ini adalah sampling jenuh dengan menggunakan seluruh populasi yaitu 12 Kabupaten/Kota di Provinsi Riau selama periode 2017 -2019, sehingga berjumlah 48 sampel.

Tekhnik analisis data yag digunakan adalah analisis Regresi Linear Berganda dengan menggunakan persamaan berikut :

$$
T P T=a+B 1 R L S+B 2 H L S
$$

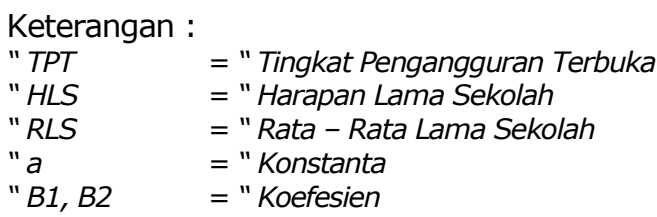

\section{HASIL DAN PEMBAHASAN}

\subsection{Uji Normalitas}

Setelah melakukan Uji normalitas menggunakan teknik Monte carlo, maka di dapat output sebagai berikut :

Tabel 1. Uji normalitas

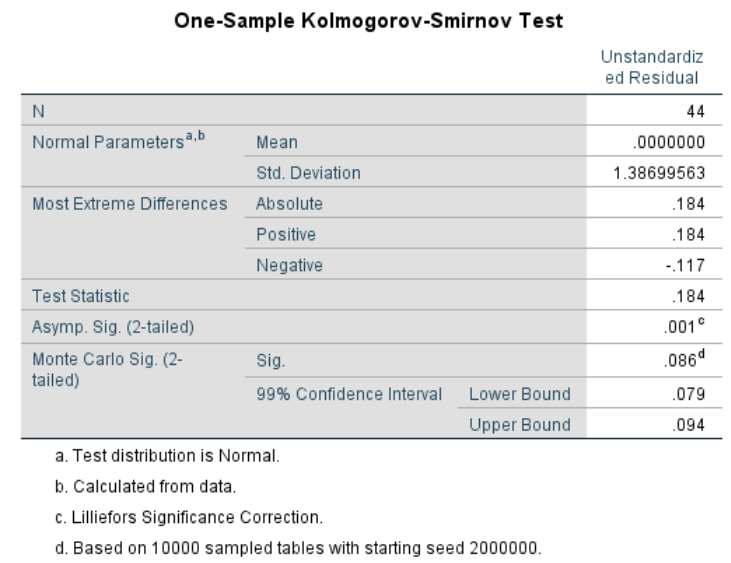

(Sumber: OUTPUT SPSS VERSI 24)

Dari Tabel output di atas maka terlihat bahwa nilai signifikansi lebih dari 0,05 yang berati data pada penelitian ini berdistribusi normal. 


\subsection{Uji Autokorelasi}

Tabel 2. nilai signifikan

\begin{tabular}{|c|c|}
\hline \multicolumn{2}{|c|}{ Runs Test } \\
\hline & $\begin{array}{l}\text { Unstandardiz } \\
\text { ed Residual }\end{array}$ \\
\hline TestValue ${ }^{a}$ & -.40835 \\
\hline Cases < Test Value & 22 \\
\hline Cases $>=$ Test Value & 22 \\
\hline Total Cases & 44 \\
\hline Number of Runs & 17 \\
\hline$z$ & -1.678 \\
\hline Asymp. Sig. (2-tailed) & .093 \\
\hline
\end{tabular}

(Sumber: OUTPUT SPSS VERSI 24)

Dari Output di atas diketahui bahwa nilai signifikansinya lebih dari 0,05 yang berarti bahwa data penelitian ini terbebas dari gejala autokorelasi.

\subsection{Persamaan Regresi Berganda}

Tabel 3. Output Coeffecients

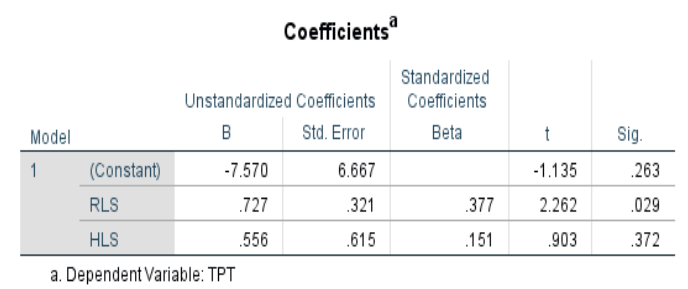

(Sumber: OUTPUT SPSS VERSI 24)

Dari Tabel Output Coeffecients diatas, maka di dapat persamaan Regresi Berganda sebagai berikut :

$T P T=-7,570+0,727 R L S+0,556 H L S$

Dengan Defenisi bahwa :

a. $A=-7,570$ yang bearti Tingkat Pengangguran terbuka akan tetap berjumlah sebesar $-757 \%$ jika variabel rata-rata lama sekolah dan variabel harapan lama sekolah konstan atau dianggap nol.

b. $\mathrm{B} 1=0,727$ yang bearti bahwa jika variabel rata-rata lama sekolah meningkat sebesar $1 \%$ maka Tingkat Pengangguran Terbuka akan meningkat sebesar $72,7 \%$.

c. $\mathrm{B} 2=0,556$ yang bearti bahwa jika ada peningkatan pada variabel harapan lama sekolah sebesar $1 \%$ maka tingkat pengangguran terbuka juga akan mengalami peningkatan sebesar $55,6 \%$.

Hasil dari output persamaan regresi berganda di atas sejalan dengan penelitian yang telah dilakukan oleh Serilius Seran (2015) yang dituangkan dalam jurnal penelitiannya berjudul Hubungan Antara
Pendidikan, Pengangguran dan Pertumbuhan Ekonomi Dengan Kemiskinan.

\subsection{Uji Koefesien Determinasi}

Tabel 4. Uji Koefesien Determinasi

\begin{tabular}{|c|c|c|c|c|}
\hline \multicolumn{5}{|c|}{ Model Summary } \\
\hline Model & $\mathrm{R}$ & R Square & $\begin{array}{l}\text { Adjusted R } \\
\text { Square }\end{array}$ & $\begin{array}{l}\text { Std. Error of } \\
\text { the Estimate }\end{array}$ \\
\hline 1 & $.479^{a}$ & .229 & .192 & 1.42042 \\
\hline
\end{tabular}

(Sumber: OUTPUT SPSS VERSI 24)

Dari Output diatas, bisa kita lihat bahwa variabel Harapan Lama Sekolah dan Rata rata Lama Sekolah hanya bisa menjelaskan pengaruh terhadap variabel Tingkat Pengangguran Terbuka sebesar 22,9\%. Ini artinya bahwa sekitar 77,1 \% Variabel Tingkat pengangguran Terbuka di pengaruhi oleh variabel lain diluar penelitian ini.

\subsection{Uji Hipotesis}

4.5.1. Uji Partial

Tabel 5. Uji Partial

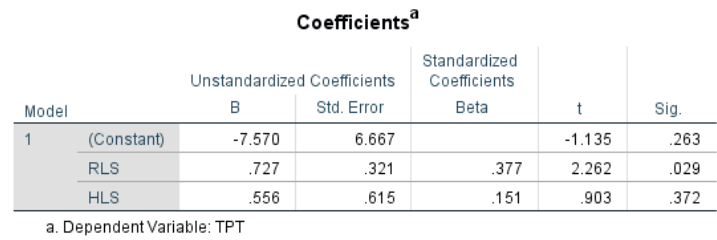

(Sumber: OUTPUT SPSS VERSI 24)

a. Pengaruh rata-rata lama sekolah terhadap tingkat pengangguran terbuka. Diketahui nilai signifikansi pada tabel output uji parsial kurang dari 0,05 yang bearti bahwa Rata - rata lama sekolah berpengaruh positif dan signifikan terhadap tingkat pengangguran terbuka. Dalam hal ini dapat diartikan bahwa semakin bertambahnya Rata-Rata Lama Sekolah maka akan bertambah pula tingkat pengangguran terbuka. Hasil penelitian ini juga sejalan dengan penelitian Serrilius seran (2015), dimana kemungkinan pertambahan tingkat pengangguran terbuka ini disebabkan naiknya gengsi bagi orang - orang yang memiliki pendidikan tinggi, karena merasa tidak sesuai dengan rendahnya upah kerja yang diterima sehingga memilih untuk menganggur sementara sampai menemukan pekerjaan dengan upah yang sesuai dengan tingginya tingkat pendidikan yang diterima.

b. Pengaruh harapan lama sekolah terhadap tingkat pengangguran terbuka. 
Diketahui nilai signifikansi pada tabel output uji parsial lebih dari 0,05 yang bearti bahwa Harapan lama sekolah tidak berpengaruh signifikan terhadap tingkat pengangguran terbuka.

\subsubsection{UJI SIMULTAN}

Tabel 6. Uji Simultan

ANOVA $^{\mathrm{a}}$

\begin{tabular}{|c|c|c|c|c|c|c|}
\hline Model & & $\begin{array}{l}\text { Sum of } \\
\text { Squares }\end{array}$ & df & Mean Square & $\mathrm{F}$ & Sig. \\
\hline \multirow[t]{3}{*}{1} & Regression & 24.619 & 2 & 12.310 & 6.101 & $.005^{\mathrm{b}}$ \\
\hline & Residual & 82.722 & 41 & 2.018 & & \\
\hline & Total & 107.341 & 43 & & & \\
\hline
\end{tabular}

Dari Output tabel di atas dapat disimpulkan bahwa nilai signifikansi kurang dari 0,05 yang mengandung arti bahwa secara simultan atau secara serentak bahwa variabel rata-rata lama sekolah dan harapan lama sekolah berpengaruh terhadap tingkat pengangguran terbuka.

\section{KESIMPULAN DAN SARAN}

\subsection{Kesimpulan}

Setelah dilakukan uji pengaruh antara dua variabel bebas atau independent yakni harapan lama sekolah dan rata - rata lama sekolah terhadap tingkat pengangguran terbuka yang bertindak sebagai variabel terikat atau dependent, sehingga menyimpulkan hasil akhir bahwa kedua variabel independent hanya memiliki pengaruh sebesar 22,9\% terhadap tingkat pengangguran terbuka, yang jika secara individu atau secara partial hanya variabel rata - rata lama sekolah yang memiliki pengaruh positif dan signifikan terhadap variabel tingkat pengangguran terbuka.

Dalam hal ini terlihat bahwa masih banyak variabel - variabel bebas yang akan mempengaruhi secara partial tingkat pengangguran terbuka yang tidak ada dalam penelitian ini.

\subsection{Saran}

Perlu dilakukan penelitian selanjutnya, agar dapat megetahui variabel - variabel apa saja yang memiliki pengaruh besar terhadap peningkatan atau penurunan pada variabel tingkat pengangguran terbuka.

\section{DAFTAR PUSTAKA}

[1] C. Hendri dan S. Imarotus, "Pengaruh Tingkat pendidikan Terhadap Tingkat Pengangguran Di Kabupaten Jombang", Jurnal Mahasiswa Universitas Negeri Surabaya, 2012.
[2] Husila S, "Analisis pengaruh inflasi, ratarata lama sekolah, pertumbuhan ekonomi, terhadap pengangguran di Provinsi Sulawesi Selatan", Jurnal Ekonomi Dan Pembangunan, 2019.

[3] https://inhilkab.bps.go.id/publication/dow nload.html?nrbvfeve =NzE4NTc5ZjdINzAw NmExYWM3M2RkYzBI

[4] R. S. Deasy, "Analisis Pengaruh Rata Rata Lama Sekolah, Upah minimum, dan Pertumbuhan Ekonomi Terhadap Tingkat Pengangguran Terbuka Kabupaten/Kota Jawa Timur", Fakultas Ekonomi Dan Bisnis Universitas Brawijaya, 2014.

[5] Seran S, " Hubungan Antara Pendidikan, Pengangguran Dan Pertumbuhan Ekonomi Dengan Kemiskinan ", Jurnal Ekonomi Kuantitatif Terapan, 2017.

[6] Sukirno, Sadono. Makro Ekonomi.Edisi Ketiga. Jakarta: PT. Raja Grafindo Persada, 2004. 